fish and a map showing the position of the banks and the area covered by the dead fish.

In addition to this branch of the Fish Commission's work, it has been doing a very important service to the country by batching shad and salmon, and partially restocking rivers with these fish. By introducing the German sarp to America a work of great economic importance was achieved, and the large number of carp-ponds in America shows the popularity of this new fish. In connection with State Fish Commissions much work is being done, which is of great importance. In every State of the Union there is now a more or less important State Fish Commission, and nearly all have been started since the National Commission, which may be considered to be the father of them all. For sevcral years naturalists of the Fish Commission have been studying the oyster problem, with the hope of in some way protecting them from their natural enemies and preventing their decrease. Under the direction of Mr. J. A. Ryder important experiments upon artificial oyster-farming have attained a marked degree of success, and within a comparatively few years it may be expected that oyster-culture in America will be revolutionised. There are at present experiments in progress upon the transplantation of certain desirable shell-fish from the east coast to the west coast of America. Owing to the extreme difference in character between the water of the two coasts, it is doubtful if these experiments will succeed.

For the purpose of studying the economic problems it is necessary that men be sent to different parts of the American coast, and these men are always instructed to study the fauna and make collections. These collections are all, after careful study by the Fish Commission naturalists, turned over to the United States National Museum, and in this way her zoological collections are vastly increased. The collections made by the Fish Commission steamers are of vast scientific importance, and they greatly add to the interest and value of the zoological branch of the National Museum collection. It is also the plan of the Fish Commission to distribute sets of duplicates from their collections to the different Museums of the country. Nearly 200 such sets have already been distributed, and special sets are made up for exchange with foreign Museums. It has been the policy of the Commission to carefully study American fisheries and the apparatus in use both in this country and abroad, and by this means find out the most improved apparatus and have it adopted in America. It was with this object in view that complete sets of American apparatus were sent to the Exhibitions held at Berlin and London, and that experts were sent to study the forcign exhibits. Already the effects of these studics are being felt in America, and American fishermen, having learned in the past to respect the Commission's advice, are beginning to adopt necded reforms in vessels and outfit. It is hoped that the American exhibits had some similar effect upon the fisheries of other nations.

The Fish Commission's work in its original conception was really the solution of practical economic problems, and it has in the main adhercd to this idea. Hence its scientific work has becn mainly upon animals which are in some way connccted with such problems, the work in very deep-sca dredging being an exceptional but natural deviation from the rather uninteresting study of the shallow fishing-grounds to the rich ficld of deep-sea research. As this work can be carricd on in addition to and without interfering with the regular work of the Commission, there is no chance for complaint. To the scientific world it is very important that this is the case. Dealing with the problems that it has, the natural history work of the Fish Commission has, of necessity, been mainly of a systematic character, dealing with species and their distribution more than with problems of anatomy, embryology, and histology. But there has been also much embryological work, that of Mr. Ryder upon certain economic fish and the oyster being of most importance. In addition to this natural history work, there has been the gathering together of complete collections of all apparatus used in connection with the fisheries, which have been placed in the National Museum. At some future time they will possess an immense scientific value.

The scientific and important practical results of the Commission's work are mainly set forth in the publications of the Fish Commission or the National Museum, but some of the monographs, and also synopses of species, which require better plates than the Government publications ordinarily contain, or need to be published in haste, are printed in some other publications. The Commission publishes an Annual Bulletin and an Annual Report. The former is printed in parts, a few pages at a time, and sent to scientific men as soon as published, and afterwards gathered into volumes. Four have been printed up to date, and they contain miscellaneous articles, many of considerable scientific importance. The Report is published annually, and contains the larger reports upon different questions and general monographs of groups of animals. There are nine volumes already published, and they cover the years of the Commission's work up to I $88 \mathrm{r}$. Many of the reports contain articles of great importance to the scientific world. RALPH S. TARR

\section{THE INSTITUTION OF ENGINEERS ANI SHIPBUILDERS IN SCOTLAND}

A GREAT amount of valuable scientific work, of a special character, is done by the various engineering institutions of the country; and much of the progress latterly made in the practical applications of science to mechanical operations, and also in the advancement of those sciences which bear most directly upon engineering work, is largely due to the growth of these institutions. The principal one-that of the Institution of Civil Engineers - may be regarded as the parent institution, not only by reason of its age, but also because of its high standing and the quality of its work. The Institution of Civil Engineers has contributed, in a very important degree, towards transforming engineering from the position of a "base mechanical" calling into one which ranks high among learned and scientific professions.

The great success and usefulness of the Institution of Civil Engineers has gradually led to its work becoming more and more differentiated, and to certain special branches of it being taken up by other institutions that have been formed for the purpose. We thus find the Institutions of Mechanical Engincers, Telegraph Engineers, Naval Architects (in which marine engineers are included), the Iron and Steel Institute, and others. All of these institutions are in a prosperous condition, and enrol a large number of new members every year. They have been most successful, without exception, both professionally and scientifically. While, on the one hand, they have benefited their members by collecting papers and providing opportunities of discussion upon points of vital interest to them in the pursuit of their various callings, they have also, on the other hand, carried scientific investigation forward in directions which would otherwise have been much neglected. The field of science-and particularly the inductive side of it - has been greatly extended by the able and thorough--though often unobtrusive-work which has been done by the engineering institutions.

It is not in the metropolis alone, however, that such institutions are now to be found. They supply too universal a want to admit of being centred in any one part of the country. We have just received from Glasgow the twenty-seventh annual volume of the Transactions of a well-known and excellent institution which exists in that city, viz. that of the Engineers and Shipbuilders in 
Scotland. This Institution is not restricted to the marine or any other special branch of engineering, but includes among its members civil and mechanical engineers of all classes, metallurgists, marine engineers, and shipbuilders. Its published volumes of Trunsactions usually contain papers of a varied and instructive character, and very valuable communications from some of the most eminent Clyde engineers are to be found in them. The importance of this Institution may be judged of by the fact that the number of its members, associates, and graduates amounts to $58 \mathrm{I}$.

The volume of Transactions just issued contains papers and discussions upon the properties of the compound engine, the stability of ships, screw piles, the testing of turbines, cable tramways, and other subjects. There is also a Presidential Address, delivered by the President, Mr. James Reid, of the Springburn Locomotive Works. Mr. Reid reviews briefly many of the latest engineering achievements that have been recorded, or that are being attempted. He refers to railway operations in this country and abroad, tramways, steam-shipping, docks, harbours, canals, bridges, hydraulic and electrical machinery, gas, and smoke combustion. Where the range of subjects is so varied and extensive, the briefest references are usually of course all that are possible.

Mr. Reid points out, with regard to railway traffic, the beneficial results of lower fares and other increased facilities in not only wonderfully augmenting the volume of thirdclass traffic, but also in adding, upon the whole, to the receipts of the railway companies. "As the downward movement of classes is still continuing, the outcome will most likely be a general reduction of the number of classes to two-nominally first and third, but practically first and second." The railway companies in this country yet have a most useful work to do in circulating food-supplies. The Fish League have had refrigerator cars constructed, which are working between the Scotch ports and London; and this small commencement is capable of a very large and urgently-needed development. A new departure in locomotive practice has been taken by M. Anatole Mallet in France, and by Mr. F. W. Webb in England, by compounding the engines. The results thus obtained are stated to be very satisfactory, although the maximum economy that is practically possible can of course only be obtained by steam-jacketing the cylinder, or by the use of superheated steam.

The advances that have recently been made in steamshipping are referred to. The fastest voyage made by any steamer prior to October 23, 1883, was that of the Alaska, in which she ran 2784 miles, between Queenstown and New York, in 6 days, 2 I hours, and 40 minutes. Mr. Reid says that this is equivalent to a mean speed of 17 miles per hour; but he speaks of miles in connection with these figures as though he were dealing with ordinary statute miles. The figures given really relate, however, to knots, or nautical miles, so that the speed of the Alaska upon the voyage in question was at the rate of over $19 \frac{1}{2}$ miles per hour. Mr. Reid also says that at an average speed of I $9 \frac{1}{4}$ miles per hour the Atlantic might be traversed in six days. The average speed requisite for crossing the Atlantic in six days is about $19 \frac{1}{2}$ knots, or $22 \frac{1}{2}$ miles, per hour, a speed which nearly amounts to that of many ordinary railway trains.

The performance of the Alaska, which Mr. Reid refers to, has been much exceeded during the present year by two Atlantic liners, the Oregon and the America. The Oregon has crossed the Atlantic in less than 6 days, Io hours, thus beating the Alaska by nearly half a day. The Umbria and Etruria, the new vessels of the Cunard Company, are expected to beat the Oregon by about as much as the latter beat the Alaska. The Umbria is said to have attained, upon the measured mile, a mean speed of $20 \frac{1}{2}$ knots, or nearly 24 miles per hour. It is possible that she may succeed in crossing the Atlantic in six days.
Passing from the wonderful strides thus making in steam-shipping, the President calls attention to the chief of the large canal schemes which are now before the world, such as the Panama Canal-which the indomitable energy of $\mathrm{M}$. de Lesseps appears likely to bring to successful completion-an independent canal across the Isthmus of Suez, and the Manchester Ship Canal. It is surprising, however, that, while referring to these various means for facilitating transit across the ocean, and also to the Channel Tunnel, Mr. Reid omits to notice the shiprailway scheme of the American engineer, Capt. J. B. Eads, C.E., which has now been for some time before the engineering world, and has received the approval of some of the most eminent authorities.

The principal papers contained in the volume of Transactions under notice are those upon the compound engine viewed in its economical aspect, by Mr. R. L. Weighton; upon the stability of ships at launching, by Mr. J. H. Biles; and on approximation to curves of stability from data for known ships, by Messrs. F. P. Purvis and B. Kindermann. Mr. Weighton's paper gives a clear and able explanation of some of those properties of the compound engine which affect its economical working; and while there is nothing novel or recondite in it, and it is somewhat amateurish in style, it is of value in keeping before the minds of engineers points of fundamental importance which it is well for them to think precisely and frequently about; and it did good service in causing one of the longest and most interesting discussions which took place during last year's meetings. We dissent entirely from an opinion expressed by one of the speakers, that "papers brought before an Institution of this kind should either expound some new theory, contain some novelty, or bring before them some important addition to the mechanical details of any machine." An exclusive striving after mere originality is not an unmixed good ; besides which, one of the greatest advantages of such institutions as that of the Engineers and Shipbuilders in Scotland is that the members become familiarised by papers and discussions which are even of a commonplace type with what is already known and thought by the most capable men upon subjects that all engineers require to thoroughly master. It is not novel points nor original conceptions only which are of value to the rank and file of members; a still more potent cause of good is to be found in the educating and informing influence which is exerted by well-established scientific ideas and recorded experience being frequently discussed, and by the constant and ready reference to fundamental and accepted principles which this involves.

The paper on the stability of ships at launching is accompanied by curves for various types of steamer at launching-draught, and advocates constructing such curves, as a rule, before launching ships. It is well worth reading, as it, and the discussion upon it, show how diverse and inconsistent though, on the whole, vague are the views held by many shipbuilders, both upon the necessity for ascertaining the precise degree of stability possessed by a ship, and also as to the sufficiency of a given amount of stability for purposes of safety. The author is somewhat ambiguous and inaccurate in his definitions of such terms as "stability," "stiffness," \&c., and inconsistent and loose in his use of them : but this appears to be a common fault with technical writers upon naval architecture, as was pointed out by Prof. Osborne Reynolds at the British Association mectings of last year. For instance it is stated in the paper under consideration that "the kind of stability which is required at launching is stiffness," and "the question of stability at launching appears therefore to reduce itself to one of stiffness,"-stiffness being represented by the metacentric height, which measures the force required to incline a given vessel through small angles from a position of rest in still water. Yet the author goes on to say that "our only safe guide is the 
complete investigation of the stability of a ship at angles considerably beyond those to which the metacentric height is a fair measure of the stiffness." He also speaks of the "stability of a ship up to $60^{\circ}$ of inclination." This is a strange although common misuse of the term "stability." Stability only exists at a position of stable equilibrium, and what is really meant by the above-quoted sentence is not stability at large angles of inclination, but righting force.

The other paper upon stability, which describes a method of approximation to curves of stability from data for known ships, is interesting in showing how some of the elements of stability vary in a ship with the ratios of draught of water to depth, and depth to breadth; but we cannot regard it as likely to be of much value in practice. The approximations obtained by applying the method are only reliable when the form of the vessel for which the curve of stability is required, and that of the one which is being used for estimating it from, are so related to each other that any section of the one may be obtained by projection from the corresponding one of the other. Differences in form are excessively numcrousalmost universal indeed-among ships; and small discrepancies of such a kind often affect stability to an important degree. When vessels are found to belong to what is defined in the paper as a "type-form," the method is applicable, but where no true type-form can be discovered for a particular ship-and this is what usually happens in practice - the only reliable and also the readiest mode of approximation to a curve of stability is to compute by means of Amsler's integrator the true length of a small number of ordinates of the curve.

There are other papers of interest in this volume which are amply deserving of perusal, though we have not space for referring in detail to them. We may note, however, as an indication of the active and enlightened interest taken by Scotch engineers in scientific teaching, that the President of the Institution of Engineers and Shipbuilders in Scotland-in referring at one of the meetings to the endowment of the John Elder Chair of Naval Architecture in Glasgow University, which is filled by Prof. F. Elgar-said that "the Council had agreed, and were morally bound, to support the institution of a lectureship in anticipation of a Chair of Naval Architecture in the University." Mr. Reid further stated that "the Council had agreed to continue the lectureship in connection with the Chair," and he wished it to be known that the original intention was still to be carried out. This is a strong practical proof of the earnestness and wise liberality of Scottish engineers in the matter of scientific and technical education, and it is a policy which cannot fail to largely benefit the district in time to come. It is also one indication, out of many, of the advantages which may confidently be looked for by engineers and scientific men as the natural outcome of such institutions as those we have referred to.

\section{THE EGGS OF MONOTREMES}

SPEAKING at the anniversary meeting of the Royal 5 Society in November 1883 , Prof. Huxley said :"It certainly was high time that British science should deal with a problem of the profoundest zoological interest, the materials for the solution of which abound in, and are at the same time confined to, those territorics of the Greater Britain which lie on the other side of the globe." These words had reference to the series of investigations which $\mathrm{Mr}$. Caldwell-the first Balfour Student - had then gone to Australia to prosecute with regard to the embryology of the lowest Mammalian forms, the Monotremes and Marsupials.

Somewhat less than a year later, and whilst the British Association was holding its meetings in Montreal, Prof. Moseley, the President of the Biological Section, was enabled to communicate the following brief but suggestive message telegraphed from Australia:-.."Caldwell finds Monotremes oviparous ; ovum meroblastic." Brief as was the message, it yet, as Prof. Moseley said, contained the most important scientific news which had been communicated to the Association in Canada.

Zoologists will now look forward with deep interest to the publication of Mr. Caldwell's more detailed account of his recent investigations, which have apparently enabled him to confirm so fully what has before been suspected, but never actually proved to be the case.

That Monotremes are oviparous has been maintained by various naturalists for now some sixty years: but up till the present time no sufficient evidence has been brought forward to place the matter beyond dispute, the chief difficulty in elucidating the problem lying in the fact that the two curious groups of animals which alone are placed in the Monotremata inhabit exclusively the Australian region, and hence have been but little studied in their natural habitat.

Though they are closely allied, yet the Ornithorhynchus and Echidna differ markedly from each other in external appearance - the one being adapted to the water, having its feet webbed, and its muzzle of that peculiar shape which has earned for it the name of Duck-billed Platypus, whilst the other is essentially a land animal, feeding on ants which it licks up by means of a long flexible tongue, and having its body covered with sharp spines, much as a hedgehog.

The question of how these animals reared their young, and in what condition the latter were born, has long been a matter of much dispute, and for information we are principally indebted to the memoirs of Home, Meckel, Geoffroy St. Hilaire, and perhaps most of all to Owen; whilst from time to time short notices are to be found in the Proceedings of the Zoological Society and the Fournal of the Linnean Society.

In I 829 Geoffroy St. Hilaire laid a communication before the Royal Academy of Sciences in Paris, entitled "Considérations sur les oufs d'Ornithorinque formant de nouveaux documens pour la question de la classification des Monotrêmes." 1 Herein he stated his opinion that the Monotremes could no longer be admitted amongst the mammals, nor could they be classified with either birds, or reptiles, or fishes, but they must, though including only two groups of animals, be formed into a distinct fifth class among the Vertebrata, which would hence be divided, according to him, into Mammals, Monotremes, Birds, Reptiles, and Fishes. ${ }^{2}$ The most interesting part of his paper, from our present point of view, however, consists of a letterwhich he quotes in full from Prof. Robert E. Grant of London, who describes in some detail the finding by a certain Mr. Holmes, whilst shooting on the banks of the River Hawksburgh in Australia, of a nest of eggs laid by an Ornithorhynchus; the animal was seen to hasten away from a.sandy bank and plunge into the water. Examination of the bank led to the discovery of a small burrow, in which, on a rude nest made of twigs, were deposited nine eggs of a peculiar shape and size, which rendered them clearly distinguishable from those of any bird. The eggs, he says, are remarkable "par une forme régulière sphćroïdale oblongue, par une égale largeur à chaque bout; ils ont (mesure anglaise), en longeur de pouce, $\mathrm{I} \frac{3}{8}$, et en largeur $\mathrm{o} \frac{\mathrm{f}}{8} ;$ la coquille est mince, fragile, légèrement transparente, et d'une couleur uniforme d'un blanc mat; sa surface extérieure, vue à la loupe, présente une texturc d'un réseau admirablement réticulé ; la matière calcaire a produit les parois blanches de ses innombrable et très-petites cellules, ce qui n'empêche pas que la surface n'en demeure à peu près polie.

I Annales des Sciences Naturclies, t. xviii. p. $x 62$; also Bulletin de $3 a$ Societé Philomathique, t. viii. p. 95 .

"The same idea is to be found also in I amarck, Philosophie Zoologique, t. i. p. r45. Lamarck adds, further, "Ce ne sont point des mammiferes; car ils sont sums mamelles, et très-vraisemblablement ovipares." 